\title{
Novel dicyanomethylene compounds from the reaction of 2-aryl-2,3- dihydro-1H-pyrrolo[3,4-b]quinoxalines with ethenetetracarbonitrile
}

\author{
Alaa A. Hassan, ${ }^{a *}$ Kamal M. El-Shaieb, ${ }^{a}$ and Dietrich Döpp ${ }^{b *}$ \\ ${ }^{a}$ Chemistry Department, Faculty of Science, El-Minia University, El-Minia, A. R. Egypt \\ ${ }^{b}$ Organische Chemie, Universität Duisburg-Essen, D-47048 Duisburg, Germany \\ E-mail: alaahassan2001@yahoo.com; doepp@uni-duisburg.de
}

Dedicated to Professor A. T. Balaban at the occasion of his $75^{\text {th }}$ birthday

(received 11 Jan 05; accepted 19 Apr 05; published on the web 28 Apr 05)

\begin{abstract}
2-Aryl-2,3-dihydro-1H-pyrrolo[3,4-b]quinoxalines 8a-d react with ethenetetracarbonitrile (TCNE) in aerated benzene with formation of [3-(2-aryl-3-dicyanomethylene-2,3-dihydro- $1 \mathrm{H}$ pyrrolo[3,4-b]quinoxalin-1-ylidene)-2-aryl-2,3-dihydro-1H-pyrrolo[3,4-b]quinoxalin-1ylidene]propanedinitriles 9a-d (41-48\%), [2-aryl-3-arylimino-2,3-dihydro-1H-pyrrolo[3,4-b]quinoxalin-1-ylidene]propanedinitriles 10a-d (19-22\%) as well as quinoxaline-2,3-diol (11, 8$11 \%)$. Rationales for these transformations are presented.
\end{abstract}

Keywords: Azaisoindoles, dehydrogenation, nitrenes, oxygenation

\section{Introduction}

The preparation and reactivity of stable azaisoindoles and benzoanellated analogues thereof have been reported. ${ }^{1-6} \mathrm{~A} \pi$-deficient anellation should make the pyrrole ring more stable towards electrophilic attack. ${ }^{5}$ On the other hand, the successful [4+2]-cycloaddition of electron deficient dienophiles, namely dimethyl ethynedicarboxylate and $\mathrm{N}$-methylmaleimide, to 2-tertbutylpyrrolo[3,4-b]quinoxaline has been reported. ${ }^{6,7}$

Previously, we have demonstrated that $\mathrm{N}$-arylisoindolines underwent charge-transfer complexation $^{8}$ as well as deep seated chemical transformations ${ }^{9,10}$ with ethenetetracarbonitrile (TCNE) under initial $\alpha$-H-atom abstraction to give $\alpha$-dicyanomethylene derivatives 2 as well as $\alpha$-oxygenated products 5 and 7 (Scheme 1). The latter two compounds also were obtained from the interaction of 1,4-benzo- or 1,4-naphthoquinones with $N$-arylisoindolines. ${ }^{11,12}$ These findings had prompted us to investigate the interaction between another $\pi$-acceptor, namely $(2,4,7-$ trinitro-9H-fluoren-9-ylidene)propanedinitrile and $\mathrm{N}$-arylisoindolines in pyridine with admission of air to give products 3, 4, 6 and 7 in moderate yields. ${ }^{13} 4$-Amino-2,7-dinitro-9-fluorenone as 
well as (4-amino-2,7-dinitro-9H-fluoren-9-ylidene)propanedinitrile also were formed ${ }^{13}$ in this complex process.

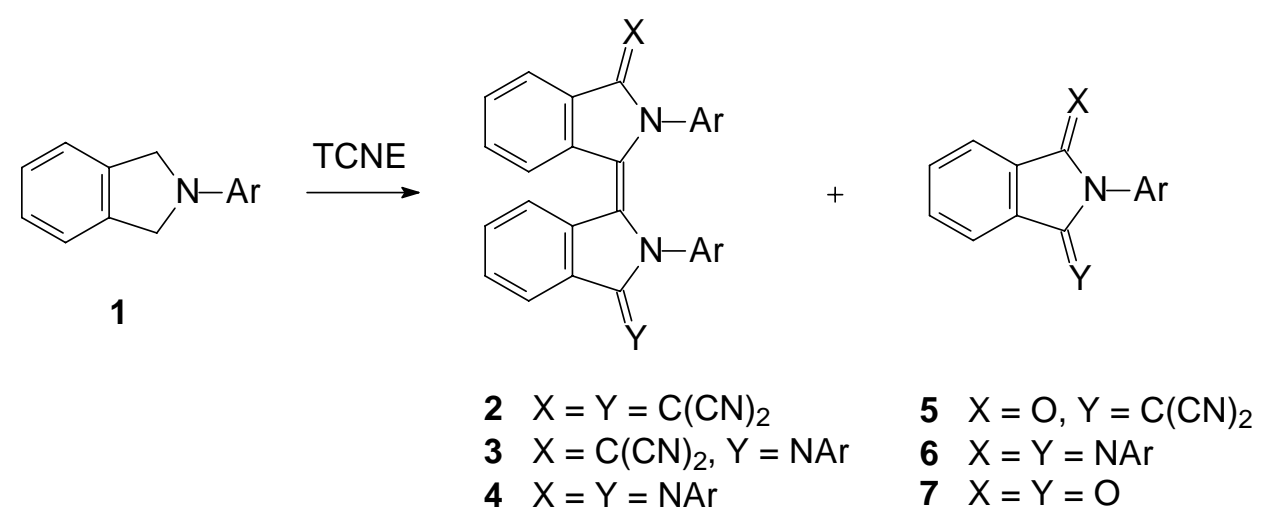

$\mathrm{Ar}=\mathrm{C}_{6} \mathrm{H}_{4} \mathrm{R}$ with $\mathrm{R}=2$ - or 3- $\mathrm{OCH}_{3}$, 2- or 3- or 4- $\mathrm{CH}_{3}, \mathrm{H}, 2$ - or 3-Cl, 4- $\mathrm{COCH}_{3}$

\section{Scheme 1}

This unique reactivity has no precedence and warrants further study. In the present investigation, we undertook the preparation of electron poorer analogues of $\mathbf{1}$, namely 2-aryl-2,3dihydro- $1 H$-pyrrolo[3,4-b]quinoxalines 8a-d, and investigated their behaviour towards TCNE.

\section{Results and Discussion}

Starting materials 8a-d were prepared from 2,3-bis(bromomethyl)quinoxaline and anilines. Upon addition of doubled molar amounts of TCNE to solutions of 8a-d in benzene with admission of air, a green colouration is observed which gradually gives way to a brown and finally to a characteristic blue colour. After concentration, the residue was subjected to vacuum sublimation to remove any unreacted TCNE. Chromatographic separation of the residue gave some tarry material and numerous coloured zones. From the three most intense zones products 9-11 could be isolated (Scheme 2).

Solutions of compounds 9a-d show a characteristic deep blue colour, attributable to the local push-pull systems of conjugated double bonds and lone pairs. The $\lambda_{\max }$ values of 9a-d in the visible spectrum (586-602 $\mathrm{nm}$ in acetonitrile solution, $\log \varepsilon 4.12-4.45)$ are very close indicating the same molecular gross structure and configuration. They are also in good agreement with the visible spectra of nine compounds of type 2 ( $\lambda_{\max } 570-584 \mathrm{~nm}, \log \varepsilon 4.33-4.84$ in acetonitrile) reported earlier. ${ }^{10}$

The structures of 9a-d are further supported by characteristic IR, NMR and mass spectral data. For example, the ${ }^{1} \mathrm{H}-\mathrm{NMR}$ spectrum of $\mathbf{9 b}$ in $\mathrm{CDCl}_{3}$ clearly shows the absence of 
methylene protons but the presence of two isochronous methyl groups located on the two phenyl rings (one singlet only at $\delta 2.30 \mathrm{ppm}$ for six protons), and phenyl protons. The gross formula $\mathrm{C}_{40} \mathrm{H}_{22} \mathrm{~N}_{10}$ for $9 \mathbf{b}$ was confirmed by the mass spectrum which exhibited the molecular ion at $\mathrm{m} / \mathrm{z}$ 642 (31\%). It should also be noted that the mass spectra of compounds 9a-d show the loss of $\mathrm{C}(\mathrm{CN})_{2}$ from the molecular ions but the correspondent fragment peaks are of relatively low intensity. The IR spectrum of $\mathbf{9 b}$ shows a sharp absorption at $2215 \mathrm{~cm}^{-1}$ characteristic for conjugated $\mathrm{C} \equiv \mathrm{N}$ groups.

The configurational assignment of compounds 9a-d needs to be adressed. In neither the Znor the $E$-isomers can the $N$-aryl group be coplanar with the adhering pyrroloquinoxaline unit. Therefore, in the E-form the "inner" quinoxaline N-atoms would show an infavourable interaction with the $N$-aryl $\pi$-systems, and the "inner" peri-protons would experience the shielding influence of the $\mathrm{N}$-aryl ring. No significantly upfield shifted aryl-H signals are detectable, however. Therefore, the $Z$ geometry is proposed as most likely for compounds 9a-d in accordance with their close structural relationship to the clearly cisoid \{3-[3-dicyanomethylene2-(3-methylphenyl)-2,3-dihydro-1 $\mathrm{H}$-isoindol-1-ylidene]-2-(3-methylphen- yl)-2,3-dihydro- $1 \mathrm{H}$ isoindol-1-ylidene $\}$ propanedinitrile $\left(2, \mathrm{Ar}=3-\mathrm{CH}_{3}-\mathrm{C}_{6} \mathrm{H}_{4}\right)$, the structure of which had been confirmed unambiguously by a single crystal $X$-ray structure analysis. ${ }^{10}$<smiles>[R4]O[R16]#N</smiles><smiles>N#CC(C#N)=C1c2nc3ccccc3nc2/C(=N/[Al])N1[Al]</smiles>

\begin{tabular}{c|l} 
8- 10 & $\mathrm{Ar}$ \\
\hline a & $\mathrm{C}_{6} \mathrm{H}_{5}$ \\
b & $3-\mathrm{CH}_{3}-\mathrm{C}_{6} \mathrm{H}_{4}$ \\
c & $4-\mathrm{CH}_{3}-\mathrm{C}_{6} \mathrm{H}_{4}$ \\
d & $4-\mathrm{CH}_{3} \mathrm{O}-\mathrm{C}_{6} \mathrm{H}_{4}$
\end{tabular}

10a-d (19-22\%)

$11(8-11 \%)$

Scheme 2 
Similarly, the structures of products 10a-d are supported by their analytical and spectral data. For example, the elemental analysis of $10 \mathrm{~b}$ suggested a gross formula $\mathrm{C}_{27} \mathrm{H}_{18} \mathrm{~N}_{6}$. This was confirmed by the mass spectrum which exhibited a molecular ion at $\mathrm{m} / \mathrm{z} 426(100 \%)$. The IR spectrum showed a strong band at $2214 \mathrm{~cm}^{-1}$ due to conjugated cyano groups. The $300 \mathrm{MHz}{ }^{1} \mathrm{H}-$ NMR spectrum also clearly indicates the absence of any signals at $\delta 4.83 \mathrm{ppm}$ expected for $\mathrm{CH}_{2}$ groups of the 1,3-dihydropyrrole ring, but shows two singlets at $\delta 2.30$ and $2.40 \mathrm{ppm}$ with a 1:1 ratio assignable to the two different methyl groups, in addition to the aromatic proton signals.

The structure of quinoxaline-2,3-diol (11) was assigned on the basis of its spectroscopic properties (see experimental part) and by comparison of its melting point with the literature value. ${ }^{14}$

The reaction conditions provide an overall dehydrogenating and oxygenating environ-ment. For the formation of the main products 9a-d, an initial didehydrogenation of the starting materials 8a-d to the fully unsaturated $2 \mathrm{H}$-pyrrolo[3,4-b]quinoxalines $\mathbf{1 2}$ seems to be most logical. This may, by analogy to the reactions of TCNE with isoindolines $\mathbf{1}$ as reported earlier, ${ }^{10}$ be effected either by a concerted hydride transfer ${ }^{15}$ from $\mathrm{C} 1$ of 8 to TCNE followed by proton transfer to generate 12 together with 1,1,2,2-tetracyanoethane $\left(\mathbf{T C N E}-\mathrm{H}_{2}\right)$, or by a consecutive (non-concerted) sequence of electron and proton transfers leading to the same products. While the colouration effects observed immediately after combination of the reactant solutions do point to the formation of charge-transfer complexes, they do not allow a clear decision in favour of the non-concerted pathway for didehydrogenation of $\mathbf{8}$ to 12. For this reaction to occur via radical ion pairs an additional electronic excitation may be required ${ }^{16}$, which is not available under the conditions used in this study.

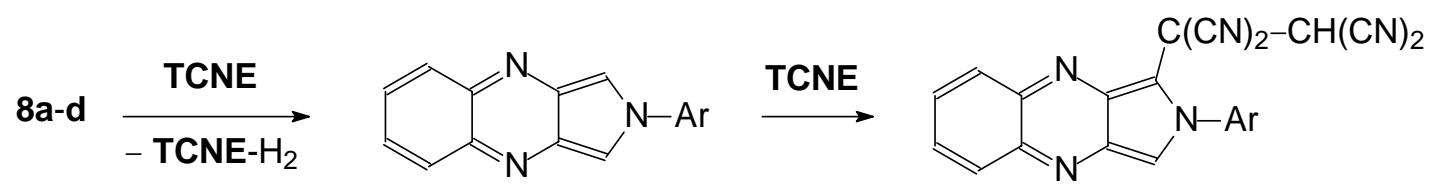

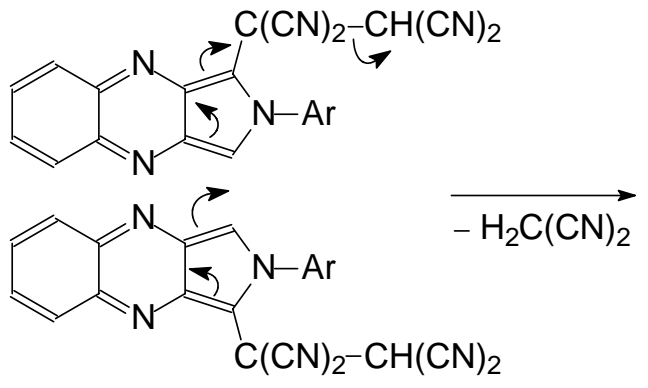

$2 \times 13$

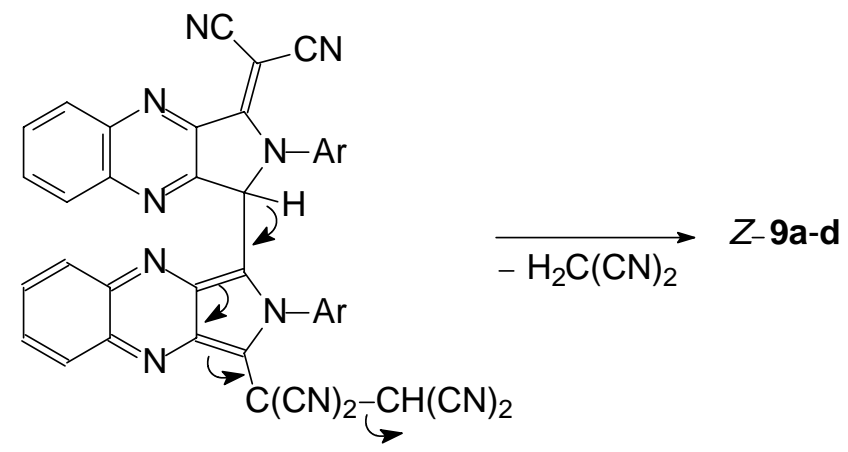

14

\section{Scheme 3}


Intermediates $\mathbf{1 2}$ are not isolated and very likely in turn react with TCNE to form tetracyanoethylated products $\mathbf{1 3}$ (Scheme 3), while there is so far no indication of formation of Diels-Alder type cycloadducts. The conversion $\mathbf{1 2} \rightarrow \mathbf{1 3}$ is in fact the first step of a so-called tricyanovinylation. ${ }^{17}$ Instead of expelling one molecule of hydrogen cyanide, however, two molecules of $\mathbf{1 3}$ react (in analogy to the case reported before ${ }^{10}$ ) to form Z-9 via 14 with successive release of two molecules of malononitrile (Scheme 3). This sequence is a dehydrogenative symmetric coupling and at the same time an $\alpha$-dicyanomethylenation. A closely analogous introduction of a dicyanomethylene group has been observed in the reaction of 1hydroxy-2-phenylindole with TCNE yielding (1-oxido-2-phenyl-3H-indol-3ylidene)propanedinitrile. ${ }^{18}$ In contrast to the case reported here, 2-unsubstituted isoindoles (as 1phenylisoindole) seem to undergo oxidative bimolecular couplings via their radical cations. ${ }^{19,20}$

The formation of products 10a-d also clearly involves the conversion of two molecules of starting material 8a-d, one being dehydrogenated to 12 and further converted into 13, the other being degraded to provide a source of the ( $N$-aryl)imino function. An electrophilic aryl-nitogen species attacking C3 of $\mathbf{1 3}$ would most logically serve this purpose. The nature of this species, however, has not been unraveled yet. An arylnitrene 18, as proposed in Scheme 4, is just one possibility.

Several reports of either cheletropic or stepwise release of nitrogen species from various types of 1,4-dihydro-1,4-iminonaphthalenes or higher anellated anlalogues thereof are found in the literature, the prime motive of which is removal of the imino bridge to generate anellated arenes. In all cases, prior to extrusion, the imino nitrogen atom is attached to an electrophilic atom or group, such as oxygen from a peracid, ${ }^{21,22}$ nitrosyl, ${ }^{23}$ dichlorocarbene, ${ }^{24}$ amino (followed by dehydrogenation), ${ }^{25,26}$ but also dimethyl ethyne dicarboxylate ${ }^{27}$ and benzyne ${ }^{27}$. It had been suggested $^{27,28}$ that the latter two form zwitterionic adducts from 1,4-iminonaphthalenes by C-N bond heterolysis, and that these zwitterions either release the naphthalene or undergo cyclization to 1,2-heteroanellated naphthalenes.

Thus, TCNE could, by analogy to the abovementioned behaviour of dimethyl ethynedicarboxylate, ${ }^{27}$ add to $\mathrm{N} 2$ of $\mathbf{8}$, and the resulting zwitterion $\mathbf{1 5}$ could release $\mathbf{1 6}$ and the betaine 17 (Scheme 4). Either 17 or the nitrene 18 released therefrom could serve as electrophilic agent on 13. With 18 (in a prototypical sense) intermediate 19 would be formed, which in two steps would afford 10a-d with release of malononitrile. The betaine $\mathbf{1 7}$ could act in the same sense. Also, the radical cation formed from 8 and TCNE could, in principle, release the nitrene 18, and in all cases products 10a-d would finally be reached. A similar pathway had been proposed earlier for the formation of compounds $\mathbf{3}$ from isoindolines $\mathbf{1} .^{13}$ However, no products derived in any way from $\mathbf{1 6}$ have been identified so far. 


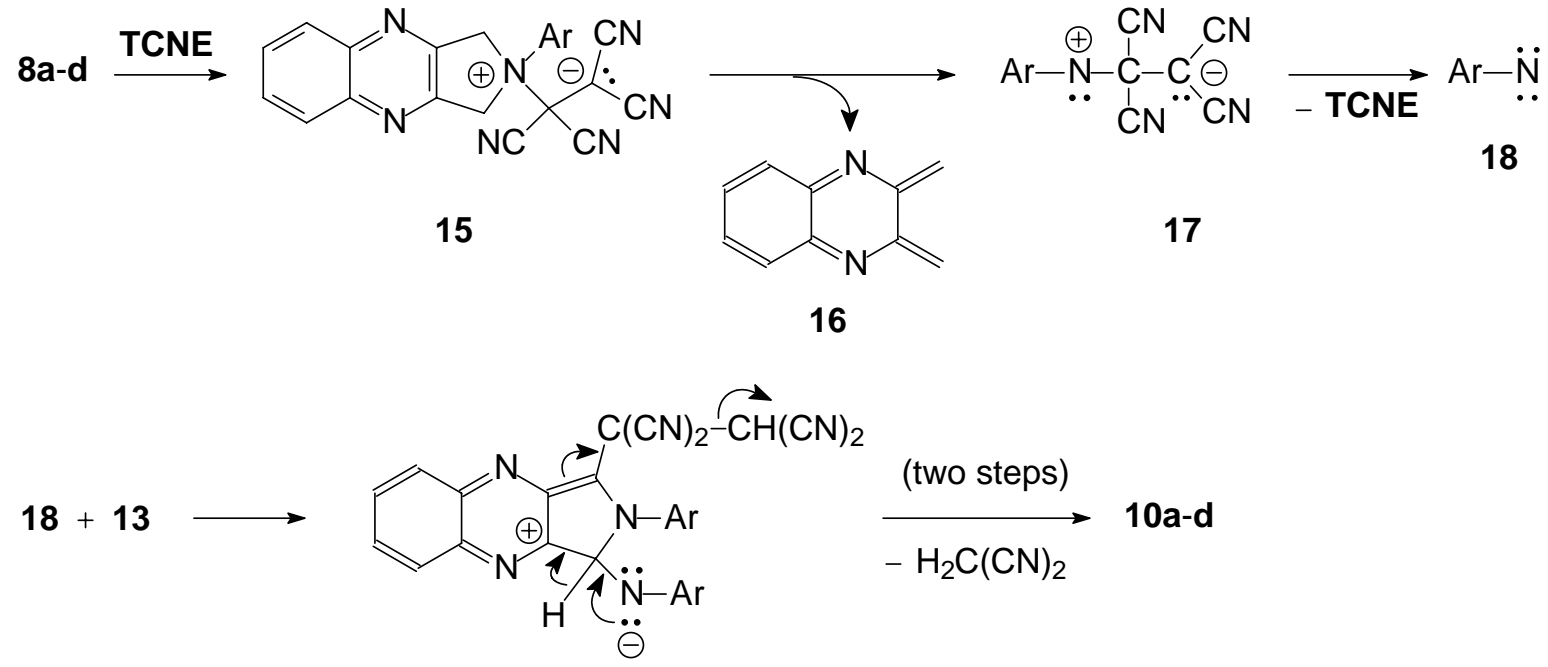

19

\section{Scheme 4}

Last, byproduct $\mathbf{1 1}$ is probably formed by a Diels-Alder type addition of oxygen to 12 followed by rearrangement of the primary adduct via 20 to 21 (not isolated). The latter compound, being sensitive to water, can generate 11 with the likely release of glyoxal mono- $(N$ aryl)imine (Scheme 5). Isoindoles are sensitive to oxygen, ${ }^{19}$ and formation of endo-peroxides which may undergo homolysis to bis-alkoxyl biradicals and further reactions thereof has been reported for a series of $N$-substituted 1,3,4,7-tetramethylisoindoles. ${ }^{29}$

When evaluating the yields it needs to be considered that the formation of both products 9 and 10 each requires the transformation of two molecules of $\mathbf{8}$. Since the reactions occurring involve numerous steps and unidentifiable tarry products are also formed, moderate yields have to be accepted.

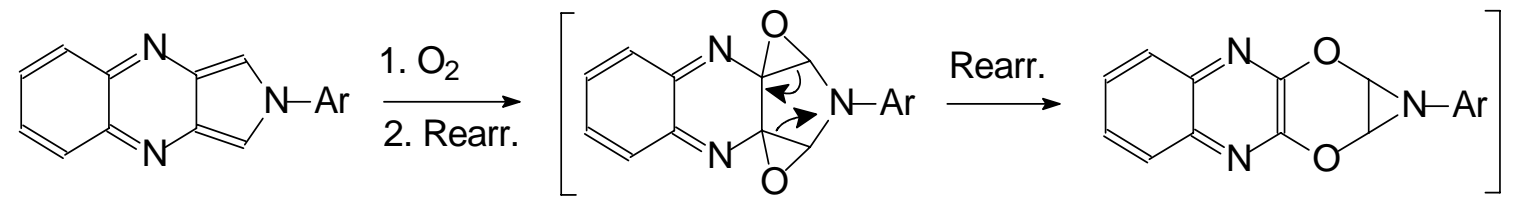

12

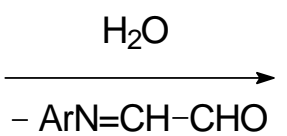

20<smiles>Oc1nc2ccccc2nc1O</smiles>

21

\section{Scheme 5}




\section{Conclusions}

As previously reported for the transformations of isoindolines $\mathbf{1}$ to products $\mathbf{2}$ and $\mathbf{3}^{10,13}$ dicyanomethylenation and overall dehydrogenative symmetric couplings of the title compounds 8a-d under the action of ethenetetracarbonitrile (TCNE) have been observed and plausibly rationalized on the basis of relevant findings taken from the literature. The results reported here supplement the rich chemisty of TCNE. ${ }^{17}$ Aza-substitution in the starting materials 8a-d did not lead to decreased reactivity towards TCNE but rather activated their methylene hydrogen atoms.

\section{Experimental Section}

General Procedures. The uncorrected melting points were determined with a Reichert Thermovar hot stage microscope. The IR spectra were obtained from $\mathrm{KBr}$ disks on either a Shimadzu 408 or a Bruker Vector 22 FT-IR instrument. The $300 \mathrm{MHz}{ }^{1} \mathrm{H}-\mathrm{NMR}$ spectra were recorded on a Bruker WM 300 instrument with tetramethylsilane as internal reference, $\mathrm{s}=$ singlet, $\mathrm{d}=$ doublet, $\mathrm{m}=$ multiplet. The mass spectra $(70 \mathrm{eV}$, electron impact mode $)$ were obtained on an AMD 604 instrument. The visible spectra were recorded on a Perkin-Elmer Lambda 2 spectrophotometer. Combustion analyses were run on a Carlo Erba Model 1106 CHN analyser, the results were found to be in good agreement $( \pm 0.2 \%)$ with the calculated values. Preparative layer chromatography was carried out using air dried $1.0 \mathrm{~mm}$ thick layers of slurry applied silica gel Merck PF254 on $48 \mathrm{~cm}$ wide and $20 \mathrm{~cm}$ high glass plates. Zones were detected by their colour or by quenching of indicator fluorescence upon exposure to $254 \mathrm{~nm}$ light.

Preparation of 2-aryl-2,3-dihydro-1H-pyrrolo[3,4-b]quinoxalines (8a-d). To a solution of $3.16 \mathrm{~g}(10 \mathrm{mmol})$ of 2,3-bis(bromomethyl)quinoxaline in $50 \mathrm{ml}$ of dry toluene, $10 \mathrm{mmol}$ of arylamine and $2.02 \mathrm{~g}(20 \mathrm{mmol})$ of triethylamine were added. The mixture was kept under reflux for $3 \mathrm{~h}$. After cooling to room temperature, the reaction mixture was filtered and the precipitate was washed thoroughly with chloroform. The washings were shaken with water, dried over anhydrous calcium chloride, and concentrated to give a yellow precipitate, which was crystallized from toluene.

2-Phenyl-2,3-dihydro-1H-pyrrolo[3,4-b]quinoxaline (8a). Yellow crystals $(1.61 \mathrm{~g}, 65 \%), \mathrm{mp}$ 246-248 ${ }^{\circ} \mathrm{C}$. IR (KBr): v 2967, $2825\left(\mathrm{CH}_{2}\right), 1516(\mathrm{Ar}-\mathrm{C}=\mathrm{C}) \mathrm{cm}^{-1} .{ }^{1} \mathrm{H}-\mathrm{NMR}\left(\mathrm{CDCl}_{3}\right): \delta 4.82(\mathrm{~s}$, 4H, $\left.2 \mathrm{CH}_{2}\right), 6.75-6.90(\mathrm{~m}, 3 \mathrm{H}, \mathrm{Ar}-\mathrm{H}), 7.25-7.42(\mathrm{~m}, 2 \mathrm{H}, \mathrm{Ar}-\mathrm{H}), 7.70-7.80(\mathrm{~m}, 2 \mathrm{H}, \mathrm{Ar}-\mathrm{H}), 8.07-$ 8.15 (m, 2H, Ar-H). MS m/z (\%): 247 (73) [M $\left.\mathrm{M}^{+}\right], 246$ (100), 219 (7), 143 (13), 109 (4), 102 (13), 91 (6), 77 (19). Anal. Calcd. for $\mathrm{C}_{16} \mathrm{H}_{13} \mathrm{~N}_{3}$ (247.29): C, 77.71; H, 5.30; N, 16.99. Found: C, 77.85; H, 5.23; N, 17.07.

2-(3-Methylphenyl)-2,3-dihydro-1H-pyrrolo[3,4-b]quinoxaline (8b). Yellow crystals $(1.83 \mathrm{~g}$, 70\%), mp 233-235 ${ }^{\circ} \mathrm{C}$. IR (KBr): v $2992\left(\mathrm{CH}_{3}\right), 2830\left(\mathrm{CH}_{2}\right), 1520(\mathrm{Ar}-\mathrm{C}=\mathrm{C}) \mathrm{cm}^{-1} .{ }^{1} \mathrm{H}-\mathrm{NMR}$ $\left(\mathrm{CDCl}_{3}\right): \delta 2.35\left(\mathrm{~s}, 3 \mathrm{H}, \mathrm{CH}_{3}\right), 4.80\left(\mathrm{~s}, 4 \mathrm{H}, 2 \mathrm{CH}_{2}\right), 6.55-6.70(\mathrm{~m}, 3 \mathrm{H}, \mathrm{Ar}-\mathrm{H}), 7.20-7.28(\mathrm{~m}, 1 \mathrm{H}$, 
Ar-H), 7.70-7.78 (m, 2H, Ar-H), 8.07-8.13 (m, 2H, Ar-H). MS m/z (\%): 261 (73) [M $\left.{ }^{+}\right], 260$ (100), 143 (10), 102 (11), 91 (16), 65 (11), 40 (11). Anal. Calcd. for $\mathrm{C}_{17} \mathrm{H}_{15} \mathrm{~N}_{3}$ (261.31): C, 78.13; H, 5.79; N, 16.08. Found: C, 78.25; H, 5.83; N, 16.17.

2-(4-Methylphenyl)-2,3-dihydro-1H-pyrrolo[3,4-b]quinoxaline (8c). Yellow crystals (1.96g, 75\%), mp 281-283 ${ }^{\circ} \mathrm{C}$. IR (KBr): v 2916 and $2842\left(\mathrm{CH}_{2}\right), 1610(\mathrm{Ar}-\mathrm{C}=\mathrm{C}) \mathrm{cm}^{-1}$. ${ }^{1} \mathrm{H}-\mathrm{NMR}$ $\left(\mathrm{CDCl}_{3}\right): \delta 2.32\left(\mathrm{~s}, 3 \mathrm{H}, \mathrm{CH}_{3}\right), 4.83\left(\mathrm{~s}, 4 \mathrm{H}, 2 \mathrm{CH}_{2}\right), 6.70(\mathrm{~d}, J=6.7 \mathrm{~Hz}, 2 \mathrm{H}, \mathrm{Ar}-\mathrm{H}), 7.20(\mathrm{~d}, J=$ $6.7 \mathrm{~Hz}, 2 \mathrm{H}, \mathrm{Ar}-\mathrm{H}), 7.75-7.86$ (m, 2H, Ar-H), 8.10-8.17 (m, 2H, Ar-H). MS m/z (\%): 261 (74) [M $\mathrm{M}^{+}$, 260 (100), 245 (5), 233 (3), 218 (5), 143 (12), 131 (4), 116 (9), 102 (10), 91 (15). Anal. Calcd. for $\mathrm{C}_{17} \mathrm{H}_{15} \mathrm{~N}_{3}$ (261.31): C, 78.13; H, 5.79; N, 16.08. Found: C, 78.05; H, 5.89; N, 15.98 .

2-(4-Methoxyphenyl)-2,3-dihydro-1H-pyrrolo[3,4-b]quinoxaline (8d). Yellow crystals (1.61g, 58\%), mp 228-230 ${ }^{\circ} \mathrm{C}$. IR (KBr) $\vee 2927$ and $2830\left(\mathrm{CH}_{2}\right), 1519(\mathrm{Ar}-\mathrm{C}=\mathrm{C}) \mathrm{cm}^{-1} .{ }^{1} \mathrm{H}-\mathrm{NMR}$ $\left(\mathrm{CDCl}_{3}\right): \delta 3.80\left(\mathrm{~s}, 3 \mathrm{H}, \mathrm{OCH}_{3}\right), 4.78\left(\mathrm{~s}, 4 \mathrm{H}, 2 \mathrm{CH}_{2}\right), 6.72(\mathrm{~d}, J=6.8 \mathrm{~Hz}, 2 \mathrm{H}, \mathrm{Ar}-\mathrm{H}), 6.96(\mathrm{~d}, J=$ $6.8 \mathrm{~Hz}, 2 \mathrm{H}, \mathrm{Ar}-\mathrm{H}), 7.70-7.80$ (m, 2H, Ar-H), 8.10-8.15 (m, 2H, Ar-H). MS m/z (\%): 277 (73) $\left[\mathrm{M}^{+}\right], 276$ (48), 262 (57), 246 (3), 232 (10), 143 (7), 102 (10), 101 (21), 92 (17), 86 (100), 65 (10), 58 (44), 44 (14). Anal. Calcd. for $\mathrm{C}_{17} \mathrm{H}_{15} \mathrm{~N}_{3} \mathrm{O}$ (277.31): C, 73.63; H, 5.45; N, 15.15. Found: C, 73.55; H, 5.53; N, 15.27.

Reaction of 2-Aryl-2,3-dihydro-1H-pyrrolo[3,4-b]quinoxalines 8a-d with TCNE. A solu-tion of $2.0 \mathrm{mmol}$ of 8a-d in $30 \mathrm{ml}$ of dry benzene was added dropwise with stirring to $512 \mathrm{mg}$ (4.0 mmol) of TCNE in $40 \mathrm{ml}$ of benzene at room temperature. Stirring was continued for 7 days with admission of air. The colour of the mixture gradually changed from green to brown and finally gave way to a blue colour. The reaction mixture was concentrated to dryness and the residue subjected to sublimation at $80{ }^{\circ} \mathrm{C}$ under vacuum to remove all unreacted TCNE. The residue was then separated by preparative layer chromatography using cyclohexane/ethyl acetate 3:1 as eluent to give numerous coloured zones, the three most intense of which were removed and extracted with acetone. The concentration residue was rechromatographed with the same eluent to enhance separation. The fastest migrating zone, which quenched all indi-cator fluorescence upon exposure to $254 \mathrm{~nm}$ UV-light, contained quinoxaline-2,3-diol (11), the second zone (orange colour) contained compounds 10a-d, whereas the most slowly migrating zone (which is always characterized by a deep blue colour) contained compounds 9a-d. The dried extracts were crystallized from suitable solvents.

[3-(3-Dicyanomethylene-2-phenyl-2,3-dihydro-1H-pyrrolo[3,4-b]quinoxalin-1-ylidene)-2phenyl-2,3-dihydro-1H-pyrrolo[3,4-b]quinoxalin-1-ylidene]propanedinitirile (9a). Blueblack crystals $(0.251 \mathrm{~g}, 41 \%), \mathrm{mp} 312-314{ }^{\circ} \mathrm{C}$ (acetonitrile); Vis (acetonitrile): $\lambda_{\max }(\log \varepsilon) 586$ $\mathrm{nm}$ (4.30). IR (KBr): v $2210(\mathrm{CN}), 1585(\mathrm{Ar}-\mathrm{C}=\mathrm{C}) \mathrm{cm}^{-1} .{ }^{1} \mathrm{H}-\mathrm{NMR}\left(\mathrm{CDCl}_{3}\right): \delta 7.16(\mathrm{~m}, 6 \mathrm{H}, \mathrm{Ar}-$ $\mathrm{H})$, 7.59-7.71 (m, 2H, Ar-H), 7.80-8.00 (m, 8H, Ar-H), 8.32 (m, 2H, Ar-H). MS m/z (\%): 614 (37) $\left[\mathrm{M}^{+}\right], 550$ (45), 398 (32), 295 (77), 270 (84), 133 (94), 106 (91), 44 (100). Anal. Calcd. for $\mathrm{C}_{38} \mathrm{H}_{18} \mathrm{~N}_{10}$ (614.64): C, 74.26; H, 2.95; N, 22.79. Found: C, 74.38; H, 2.83; N, 22.87.

\{3-[3-Dicyanomethylene-2-(3-methylphenyl)-2,3-dihydro-1H-pyrrolo[3,4-b]quinoxalin- 1ylidene]-2-(3-methylphenyl)-2,3-dihydro-1H-pyrrolo[3,4-b]quinoxalin-1-ylidene\}prop- 
anedinitrile (9b). Blue-black crystals $(0.270 \mathrm{~g}, 42 \%), \mathrm{mp} 322-324{ }^{\circ} \mathrm{C}$ (acetonitrile); Vis (acetonitrile) $\lambda_{\max }(\log \varepsilon) 592 \mathrm{~nm}$ (4.32). IR (KBr): $v 2220(\mathrm{CN}), 1595(\mathrm{Ar}-\mathrm{C}=\mathrm{C}) \mathrm{cm}^{-1} .{ }^{1} \mathrm{H}-\mathrm{NMR}$ $\left(\mathrm{CDCl}_{3}\right): \delta 2.25\left(\mathrm{~s}, 6 \mathrm{H}, 2 \mathrm{CH}_{3}\right), 7.24(\mathrm{~m}, 4 \mathrm{H}, \mathrm{Ar}-\mathrm{H}), 7.63-7.72(\mathrm{~m}, 4 \mathrm{H}, \mathrm{Ar}-\mathrm{H}), 7.82-8.00(\mathrm{~m}, 6 \mathrm{H}$, Ar-H), 8.35 (m, 2H, Ar-H). MS m/z (\%): 642 (36) $\left[\mathrm{M}^{+}\right], 578$ (47), 552(12), 460 (16), 426(23), 323 (78), 298 (81), 133 (92), 106 (95), 44 (100). Anal. Calcd. for $\mathrm{C}_{40} \mathrm{H}_{22} \mathrm{~N}_{10}$ (642.69): C, 74.75; H, 3.45; N, 21.79. Found: C, 74.66; H, 3.33; N, 21.84.

\{3-[3-Dicyanomethylene-2-(4-methylphenyl)-2,3-dihydro-1H-pyrrolo[3,4-b]quinoxalin- 1ylidene]-2-(4-methylphenyl)-2,3-dihydro-1H-pyrrolo[3,4-b]quinoxalin-1-ylidene\}-

propanedinitrile (9c). Blue-black crystals (0.308g, 48\%), mp 343-345 ${ }^{\circ} \mathrm{C}$ (acetonitrile); Vis (acetonitrile): $\lambda_{\max }(\log \varepsilon) 596 \mathrm{~nm}$ (4.12). IR (KBr): $v 2215(\mathrm{CN}), 1579(\mathrm{Ar}-\mathrm{C}=\mathrm{C}) \mathrm{cm}^{-1} .{ }^{1} \mathrm{H}-\mathrm{NMR}$ $\left(\mathrm{CDCl}_{3}\right): \delta 2.30\left(\mathrm{~s}, 6 \mathrm{H}, 2 \mathrm{CH}_{3}\right), 7.20(\mathrm{~m}, 4 \mathrm{H}, \mathrm{Ar}-\mathrm{H}), 7.65-7.75(\mathrm{~m}, 2 \mathrm{H}, \mathrm{Ar}-\mathrm{H}), 7.85-8.05(\mathrm{~m}, 8 \mathrm{H}$, Ar-H), 8.35 (m, 2H, Ar-H). MS m/z (\%): 642 (31) $\left[\mathrm{M}^{+}\right], 578$ (45), 552 (14), 460 (14), 426 (22), 323 (76), 298 (87), 133 (96), 106 (95), 44 (100). Anal. Calcd. for $\mathrm{C}_{40} \mathrm{H}_{22} \mathrm{~N}_{10}$ (642.69): C, 74.75; H, 3.45; N, 21.79. Found: C, 74.58; H, 3.53; N, 21.62.

\{3-[3-(Dicyanomethylene)-2-(4-methoxyphenyl)-2,3-dihydro-1H-pyrrolo[3,4-b]quinox-alin1-ylidene]-2-(4-methoxyphenyl)-2,3-dihydro-1H-pyrrolo[3,4-b]quinoxalin-1-ylid-

ene\}propanedinitrile (9d). Blue-black crystals $(0.276 \mathrm{~g}, 41 \%), \mathrm{mp} 350-352{ }^{\circ} \mathrm{C}$ (dec., acetonitrile). Vis (acetonitrile) $\lambda_{\max }(\log \varepsilon) 602 \mathrm{~nm}(4.45)$. IR (KBr): $v 2210(\mathrm{CN})$, $1590(\mathrm{Ar}-\mathrm{C}=\mathrm{C}) \mathrm{cm}^{-1} \cdot{ }^{1} \mathrm{H}-\mathrm{NMR}\left(\mathrm{CDCl}_{3}\right): \delta 3.86\left(\mathrm{~s}, 6 \mathrm{H}, 2 \mathrm{OCH}_{3}\right), 7.18(\mathrm{~m}, 4 \mathrm{H}$, Ar-H), 7.56-7.70 (m, 2H, Ar-H), 7.78-7.96 (m, 8H, Ar-H), 8.30 (m, 2H, Ar-H). MS m/z (\%): 674 (41) $\left[\mathrm{M}^{+}\right], 610$ (51), 568 (11), 476 (10), 442 (22), 314 (89), 133 (91), 106 (95), 44 (100). Anal. Calcd. for $\mathrm{C}_{40} \mathrm{H}_{22} \mathrm{~N}_{10} \mathrm{O}_{2}$ (674.69): C, 71.21; H, 3.29; N, 20.76. Found: C, 71.18; H, 3.33; N, 20.85.

[2-Phenyl-3-phenylimino-2,3-dihydro-1H-pyrrolo[3,4-b]quinoxalin-1-ylidene]propanedinitrile (10a). Orange crystals $(0.076 \mathrm{~g}, 19 \%), \mathrm{mp} 288-290{ }^{\circ} \mathrm{C}$ (ethanol). IR (KBr): $2215(\mathrm{CN})$, $1600(\mathrm{Ar}-\mathrm{C}=\mathrm{C}) \mathrm{cm}^{-1} .{ }^{1} \mathrm{H}-\mathrm{NMR}\left(\mathrm{DMF}-\mathrm{d}_{7}\right): \delta$ 7.10-7.65 (m, 6H, Ar-H), 7.88-8.12 (m, 6H, Ar-H), 8.34 (m, 2H, Ar-H). MS m/z (\%): 398 (100) [ $\left.\mathrm{M}^{+}\right], 376$ (16), 296 (10), 189 (9), 164 (7), 91(32). Anal. Calcd. for $\mathrm{C}_{25} \mathrm{H}_{14} \mathrm{~N}_{6}$ (398.44): C, 75.36; H, 3.54; N, 21.09. Found: C, 75.19; H, 3.43; N, 21.16.

[2-(3-Methylphenyl)-3-(3-methylphenylimino)-2,3-dihydro-1H-pyrrolo[3,4-b]quinoxalin- 1-ylidene]propanedinitrile (10b). Orange crystals $(0.085 \mathrm{~g}, 20 \%), \mathrm{mp} 296-298{ }^{\circ} \mathrm{C}$ (ethanol). IR $(\mathrm{KBr}): v 2215(\mathrm{CN}), 1620(\mathrm{Ar}-\mathrm{C}=\mathrm{C}) \mathrm{cm}^{-1} .{ }^{1} \mathrm{H}-\mathrm{NMR}\left(\mathrm{DMF}-\mathrm{d}_{7}\right): \delta 2.28\left(\mathrm{~s}, 3 \mathrm{H}, \mathrm{CH}_{3}\right), 2.40(\mathrm{~s}, 3 \mathrm{H}$, $\left.\mathrm{CH}_{3}\right)$, 7.00-7.66 (m, 6H, Ar-H), 7.74-8.10 (m, 4H, Ar-H), 8.32 (m, 2H, Ar-H). MS m/z (\%): 426 (100) $\left[\mathrm{M}^{+}\right], 400$ (15), 320 (16), 213 (11), 178 (10), 117 (25), 91 (29). Anal. Calcd. for $\mathrm{C}_{27} \mathrm{H}_{18} \mathrm{~N}_{6}$ (426.49): C, 76.04; H, 4.25; N, 19.71. Found: C, 75.96; H, 4.33; N, 19.56.

[2-(4-Methylphenyl)-3-(4-methylphenylimino)-2,3-dihydro-1H-pyrrolo[3,4-b]quinoxalin- 1-ylidene]propanedinitrile (10c). Orange crystals $(0.094 \mathrm{~g}, 22 \%), \mathrm{mp} 318-320{ }^{\circ} \mathrm{C}$ (ethanol). IR $(\mathrm{KBr}): v 2214(\mathrm{CN}), 1610(\mathrm{Ar}-\mathrm{C}=\mathrm{C}) \mathrm{cm}^{-1} .{ }^{1} \mathrm{H}-\mathrm{NMR}\left(\mathrm{DMF}-\mathrm{d}_{7}\right): \delta 2.30\left(\mathrm{~s}, 3 \mathrm{H}, \mathrm{CH}_{3}\right), 2.40(\mathrm{~s}, 3 \mathrm{H}$, $\left.\mathrm{CH}_{3}\right), 7.20(\mathrm{~d}, J=6.7 \mathrm{~Hz}, 2 \mathrm{H}, \mathrm{Ar}-\mathrm{H}), 7.70(\mathrm{~d}, J=6.5 \mathrm{~Hz}, 2 \mathrm{H}, \mathrm{Ar}-\mathrm{H}), 7.80-8.15$ (m, 6H, Ar-H), 8.35 (m, 2H, Ar-H). MS m/z (\%): 426 (100) $\left[\mathrm{M}^{+}\right], 400$ (11), 320 (18), 213 (8), 178 (6), 117 (15), 
91 (31). Anal. Calcd. for $\mathrm{C}_{27} \mathrm{H}_{18} \mathrm{~N}_{6}$ (426.49): C, 76.04; H, 4.25; N, 19.71. Found: C, 75.88; H, $4.38 ; \mathrm{N}, 19.58$.

[2-(4-Methoxyphenyl)-3-(4-methoxyphenylimino)-2,3-dihydro-1H-pyrrolo[3,4-b]quinoxalin-1-ylidene]propanedinitrile (10d). Orange crystals $(0.096 \mathrm{~g}, 21 \%), \mathrm{mp} 324-326{ }^{\circ} \mathrm{C}$ (ethanol). IR (KBr) v $2220(\mathrm{CN}), 1610(\mathrm{Ar}-\mathrm{C}=\mathrm{C}) \mathrm{cm}^{-1} .{ }^{1} \mathrm{H}-\mathrm{NMR}\left(\mathrm{CDCl}_{3}\right): \delta 3.85\left(\mathrm{~s}, 3 \mathrm{H}, \mathrm{OCH}_{3}\right)$, $3,89\left(\mathrm{~s}, 3 \mathrm{H}, \mathrm{OCH}_{3}\right), 7.17(\mathrm{~d}, J=6.7 \mathrm{~Hz}, 2 \mathrm{H}, \mathrm{Ar}-\mathrm{H}), 7.62$ (d, $\left.J=6.7 \mathrm{~Hz}, 2 \mathrm{H}, \mathrm{Ar}-\mathrm{H}\right), 7.75-8.10$

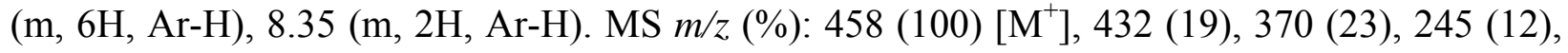
219 (9), 106 (15), 91 (31). Anal. Calcd. for $\mathrm{C}_{27} \mathrm{H}_{18} \mathrm{~N}_{6} \mathrm{O}_{2}$ (458.49): C, 70.73; H, 3.96; N, 18.33. Found: C, 70.56; H, 4.11; N, 18.26.

Quinoxaline-2,3-diol (11). Colourless crystals (8-11\%), mp 287-289 ${ }^{\circ} \mathrm{C}$ (ethanol), (lit. ${ }^{14} 285{ }^{\circ} \mathrm{C}$ ). IR (KBr): v $3466(\mathrm{OH}), 3080(\operatorname{aryl} \mathrm{C}-\mathrm{H}), 1630(\mathrm{C}=\mathrm{N}), 1590(\mathrm{Ar}-\mathrm{C}=\mathrm{C}) \mathrm{cm}^{-1} .{ }^{1} \mathrm{H}-\mathrm{NMR}\left(\mathrm{CDCl}_{3}\right)$ : $\delta$ 7.25-7.60 (m, 4H, Ar-H), 9.78 (br, 2H, 2OH). MS m/z (\%): 162 (6) [M $\left.{ }^{+}\right], 160$ (27), 134 (100), 106 (12), 77 (31), 51 (19).

\section{Acknowledgements}

A. A. Hassan is indebted to the A. v. Humboldt-Foundation for the award of a fellowship from August 2003 to Sept. 2003 and also for the donation of the Shimadzu 408 IR spectrophotometer. Financial support of this work by Fonds der Chemischen Industrie is gratefully acknowledged.

\section{References}

1. Kreher, R.; Use, G. Tetrahedron Lett. 1981, 22, 4045.

2. Anderson, R. C.; Fleming, R. H. Tetrahedron Lett. 1969, 1581.

3. Roland, M. M.; Anderson, R. C. J. Heterocyclic Chem. 1977, 14, 541.

4. Duflos, J.; Letouzé, D.; Queguiner, G.; Pastour, P. Tetrahedron Lett. 1973, 3453.

5. Armarego, W. L. F.; Milloy, B. A.; Sharma, S. C. J. Chem. Soc., Perkin Trans. I 1972, 2485.

6. Kreher, R.; Use, G. Tetrahedron Lett. 1978, 4671.

7. Kreher, R.; Mildenberger, K. Chem. Ztg. 1984, 108, 317.

8. Nour El-Din, A. M.; Mourad, A. E.; Hassan, A. A.; Döpp, D. Z. Phys. Chem. (Leipzig) 1988, $269,832$.

9. Döpp, D.; Hassan, A. A.; Nour El-Din, A. M.; Mourad, A. E. Organic Free Radicals, Proceedings of the Fifth International Symposium, Zürich,1988; Springer: Berlin, 1988; p 41.

10. Döpp, D.; Hassan, A. A.; Mourad, A. E.; Nour El-Din, A. M.; Angermund, K.; Krüger, C.; Lehman, C. W.; Rust, J. Tetrahedron 2003, 59, 5073.

11. Hassan, A. A. Ph.D. Thesis, El-Minia University 1988.

12. Hassan, A. A. Bull. Soc. Chim. Fr. 1991, 128, 544. 
13. Hassan, A. A.; Döpp, D.; Henkel, G. J. Heterocyclic Chem. 1998, 35, 121.

14. Begland, R. W.; Hartter, D. R. J. Org. Chem. 1972, 37, 4136.

15. Net hydride abstractions have been demonstrated to occur from tertiary amines analogous to 1 with TCNE and 2-dicyanomethyleneindan-1,3-dione: Döpp, D.; Jüschke, S.; Henkel, G. Z. Naturforsch. 2002, 57b, 460.

16. For a review on various chemical transformations of selected organic donors with or mediated by TCNE, see: Bruni, P.; Tosi, G. Gazz. Chim. Ital. 1997, 127, 435.

17. Fatiadi, A. J. Synthesis 1986, 249, and references cited therein.

18. Tosi, G.; Cardellini, L.; Cardillo, B.; Bocelli, G. Monatsh. Chem. 1987, 118, 369.

19. Bonnett, R.; North, S. A. Adv. Heterocycl. Chem. 1981, 29, 341.

20. Bonnett, R.; North, S. A; Newton, R. F.; Scopes, D. I. C. Tetrahedron 1983, 39, 1401.

21. Gribble, G. W.; LeHoullier, C. S.; Sibi, M. P.; Allen, R. W. J. Org. Chem. 1985, 50, 1611.

22. Gribble, G. W.; Allen, R. W.; Anderson, P. S.; Christy, M. E.; Colton, C. D. Tetrahedron Letters 1976, 3673.

23. Carpino, L A.; Barr, D. E. J. Org. Chem. 1966, 31, 764.

24. Gribble, G. W.; Allen, R. W.; LeHoullier, C. S.; Eaton, J. T.; Easton, N. R., jr.; Slayton, R. I.; Sibi, M. P. J. Org. Chem. 1981, 46, 1025.

25. Carpino, L. A. J. Org. Chem. 1969, 34, 461.

26. Carpino, L.A.; Padykula, R. E.; Barr, D. E.; Hall, F. H.; Krause, J. G.; Dufresne, R. F.; Thoman, C. J. J. Org. Chem. 1988, 53, 2565.

27. Kricka, L. J.; Vernon, J. M. J. Chem. Soc., Perkin Trans. I 1973, 766.

28. Kricka, L. J.; Vernon, J. M. Adv. Heterocycl. Chem. 1974, 16, 87

29. Vernon, J. M.; Kricka, L. J. J. Chem. Soc. (C) 1971, 2667. 